M. Ebrahemzadih*

\title{
ESTIMATES OF SAFETY DISTANCES FOR HYDROGEN SULFIDE LEAK EMISSION FROM GAS REFINERY
}

UDK 661.9:546.221.11:614.83

RECEIVED: $2015-10-27$

ACCEPTED: 2016-05-02

\begin{abstract}
SUMMARY Refinery processes need to organise and maintain work places safe for their workers, neighbours and the environment. Refineries are the source of many accidents and incidents due to the close proximity of dangerous substances, products and production processes. The aim of this study was to analyse the consequences of hydrogen sulphide leakage scenarios in gas refineries and determine the danger boundary and the risk limits of these scenarios. The study was descriptiveanalytic cross-sectional and was carried out in gas refineries. To assess the gas dispersion modality and the effects of leakage scenarios the PHAST software (Process Hazard Analysis Software Tool) was used. Different leakage scenarios were considered and then various climatic conditions affecting these scenarios were identified. Ultimately, the consequences and the danger boundary and risk limits of these scenarios for the affected areas were determined with two-level criteria, LC (lethal concentration) and IDLH (immediately dangerous to life or health). The findings demonstrated that the hazard distance LC50 for hydrogen sulphide dispersion to restricted areas and the hazard distance of the IDLH for hydrogen sulphide toxic dispersion to impacted area were 224 meters and 386 $m$, respectively. Also, the results revealed that the ENI camp was situated in the dominant current direction, at a $200 \mathrm{~m}$ distance from gas refineries. In the event of a leakage accident, substantial loss of life and health damages can be expected. Consequently, it is mandatory that the location of the residents' camp be changed and appropriate engineering control measures taken.
\end{abstract}

Key words: process accidents, gas refineries, hydrogen sulphide leak, restricted area, impacted area

\section{INTRODUCTION}

There have always been potential hazards in the petroleum and gas industries that can cause severe and irreparable injuries and financial losses (Revie, 2015). The processing accidents are the largest and most frequent causes of erroneous costs in industries, refineries, and Mega projects in Iran. Determination of the damage limit, impact rate and the scenario occurrence

*Mehrzad Ebrahemzadih, P.E, T.A, (M.Ebrahimzadeh@muk.ac.ir, Emhrzad@yahoo.com), Environmental Health Research Center, Kurdistan University of Medical Sciences, Sanandaj, Iran. Postal code: 66811-16434, Department of Occupational Safety \& Health, Faculty of Health, Medical Campus, Pasdaran Street, Sanandaj, Iran. of these accidents have special importance in recognition and control of the risk in these scenarios (USA Department of Defence, 1980). To take security measures in the surrounding area of the gas refineries, there must be a design for checking the damage sources, e.g., the processing pipelines, the spherical tanks, the distillation columns, etc. Then, the outcomes of different scenarios involved in the creation of the crisis should be analyzed. Determining the limits of the restricted and impacted areas due to occurrence of these scenarios must also be determined. Finally, controlling and defensive measures need to be taken in the impacted areas for the installations, e.g., changing location, fencing, and automation (Witkowski et al., 2015). The 
first step in studying and assessing consequences of possible accidents such as the dispersion or release of noxious and lethal materials in a processing unit is modeling of the release (Gerboni \& Salvador, 2011). Then, the model of the next consequences that can occur such as fire and/or material explosion and the damage due to the toxic material dispersion should be conducted (Gerboni \& Salvador, 2011, Witkowski et al., 2015). Most of the processing accidents include huge damages due to the nature and the extent of the use of chemical materials (Centre for Chemical Process Safety, 2000). It is worth noting that regarding the abundance of active manpower in our country, industrial projects and employment of nearly 5000 personnel in the construction and commissioning of every refinery will sustain processing occurrence of damages and human injuries. That is why the processing accidents are considered as serious scenario concerns for the commissions and international community Jafari et al., 2012). Many countries have taken preventive and controlling measures against the incidence of processing accidents according to the principles and research experiences (Centre for Chemical Process Safety, 1994). To increase the number of refinery units and their output products, we will naturally increase the number of employed staff in these industries and the resident population near them who are exposed to the hazards. As an example, the Felix Borough factory accident caused 28 people to be killed and 26 to be injured in England in 1974 (Advisory Committee on Major Hazards, 1984). Another similar occurrence was a chemical accident in Bhopal, India, in 1984 ( $L u$ et al., 2015). The accident resulted in 2500 intoxication cases and 10 times more injuries. Also 11 people were killed in Mexico Golf by leakage and fire of petroleum from gas rigs of BP (British Petroleum) and the imposed damages were more than $\$ 40$ billion. Besides, the disaster caused 22 $\%$ drop in the stock value and $63 \%$ decrease in profit (McCrea-Strub et al., 2012). The PHAST software (Process Hazard Analysis Software Tools) is a comprehensive line analysis tool for line analysis of the danger and determination of the secure privacy in the developed countries. This software with easy application and flexibility and high accuracy, allows the user to analyze different amounts for vast limits of the model parameters (Dziubiński et al., 2006). The study by Nadimi entitled: "Dispersion modeling of $\mathrm{CO}_{2}$ Escaping from Steel Industries" used PHAST to determine the rate of pollution (Nadimi et al., 2011). Also, in the study by Jianwen et al. entitled: "Assessment of Quantitative Risk of Dangers of Gas Transmission and Distribution" PHAST was used to analyze the accidents (Jianwen \& Wenxing, 2014). Besides, Chiara Vianella used PHAST to determine the safe privacy in their study entitled: "Designing a Conceptual Model of Risk Assessment of Hazards due to $\mathrm{CO}_{2}$ Dispersion" (Vianello et al., 2012). The South Pars Gas Field is one of the greatest gas sources in the world located on the common border between Iran and Qatar. It is one of the main sources of the energy of the country. This field has an area of $9700 \mathrm{~km}^{2}$ with $3700 \mathrm{~km}^{2}$ belonging to Iran. The gas reservoir of this section is speculated to be 14 trillion $\mathrm{m} 3$ of gas along with 18 billion $\mathrm{m}^{3}$ liquid gas. This comprises $7.5 \%$ of the world gas reservoir and about $50 \%$ of the country's gas. The refinery installations of South Pars Phases 2 \& 3 were delivered to Total Consortium, Gas prom, and PETRONAS under a buyback contract for daily extraction of 2000 million cubic feet of gas, 80000 barrels of liquid gas, and 400 tons of sulfides in September, 1998. The submarine instaIlations include two three-welled rigs for digging twenty development wells, two 32-inch submarine pipelines, and two 4.5-inch off-shore pipelines for the transmission of the mixture of Mono Ethylene Glycol and Amine from the shore to the rigs, each with $105 \mathrm{~km}$ length. The gas refinery installations of these two phases including four operational rows in the shore with 50 million $\mathrm{m}^{3}$ have been already installed. These include gas and liquid gas receiving and separation units, liquid gas stabilization and also sweetening dehydration and dew point setting, demercaptannization and gas contraction for transmission recovery and sulfur solidification, torch and its auxiliary equipment, and receiving of mono-Ethylene Glycol for transmission with 4.5-inch pipeline and injection to the transmission 32-inch pipelines. The purpose of this study was to determine the danger zones for impacted and affected (restricted) areas, regarding the hydration sulfide gas leakage scenario. 


\section{METHODS}

This was a descriptive-analytic cross-sectional study conducted in one of Gas Refinery in south Iran. There are various methods for consequence assessment all of which have similar structure and output. However, there are differences in their details and process division. Consequence modeling includes modeling materials release in the environment and subsequently, modeling the consequences due to toxicity, inflammation or explosion of these substances. As these models are complex and time-consuming, so, they are solved by the use of computers. To do so, the PHAST 6.54 software (Process Hazard Analysis Software Tool) was selected as it is the best and one of the most accurate instruments offered for environmental risk modeling (Dziubiński et al., 2006). It has been known as one of the tools of decision-making used by people, states, and firms in industrial hazards and common immunity (Schubach, 1995). The present study investigated the modeling of the most important foci of hazards in South Pars Gas Refinery Phases $2 \& 3$. In so doing, the clot stuck unit of South Pars Refinery Phases 2 and 3 were surveyed for fire load and different scenarios were considered for each unit. The consequence of each scenario was determined to speculate the restricted (affected) and impacted areas. As it is true with other modelling practices, to operationalize this process, there will be the need for actual data along with the application of some hypotheses and assumptions. The characteristics and information related to the dispersion site of $\mathrm{H} 2 \mathrm{~S}$ form the clot stuck unit and also data related to the required climatic conditions were recorded for modelling (Table $1 \&$ Table 2 ). The culled data were then given to PHAST.
Table1. Specifications of the $\mathrm{H}_{2} \mathrm{~S}$ pipeline with the leak in the modelling

Tablica 1. Specifikacije $\mathrm{H}_{2} \mathrm{~S}$ plinovoda $\mathrm{s}$ modelom istjecanja

\begin{tabular}{||l|c||}
\hline Release location & size/type \\
\hline Line diameter (inch) & 32 \\
\hline Release dia. $(\mathrm{mm})$ & 140 \\
\hline Release length $(\mathrm{mm})$ & 600 \\
\hline Pressure (bar) & 60 \\
\hline The height from ground level $(\mathrm{M})$ & 3 \\
\hline Pipe material & Carbon Steel \\
\hline Pipe roughness $(\mathrm{mm})$ & 0.0178 \\
\hline
\end{tabular}

Table 2. The climate conditions in the modeling

Tablica 2. Vremenski uvjeti u modelu

\begin{tabular}{|c|c|c|}
\hline \multicolumn{2}{|l|}{ Climate Parameters } & Rate \\
\hline \multicolumn{2}{|l|}{ Temperature $\left({ }^{\circ} \mathrm{C}\right)$} & 10 \\
\hline \multicolumn{2}{|l|}{ Relative humidity (\%) } & 64 \\
\hline \multicolumn{2}{|l|}{ Wind direction } & west \\
\hline \multicolumn{2}{|l|}{ Dew point $\left({ }^{\circ} \mathrm{C}\right)$} & 0 \\
\hline \multirow{2}{*}{ Velocity of wind $(\mathrm{m} / \mathrm{s})$} & Min & 2 \\
\hline & Max & 5 \\
\hline
\end{tabular}

\section{RESULTS}

This study applied the exposure index of $\mathrm{H}_{2} \mathrm{~S}$ toxicity with two-level criteria LC (Lethal concentration) and IDLH (Immediately dangerous to life or health) to determine the secure privacy. The safe distance of the restricted and impacted areas as well as the climatic indices and parameters related to leaking $\mathrm{H}_{2} \mathrm{~S}$ transmission pipelines were identified using PHAST. Table 3 and Table 4 display the effect criteria of intoxication with $\mathrm{H}_{2} \mathrm{~S}$ (Das \& Weinberg., 2012, Rusin \& Stolecka, 2011). 
Table 3. The Toxicity criteria of $\mathrm{H}_{2} \mathrm{~S}$ for determination of the restricted areas

Tablica 3. Kriteriji toksičnosti $\mathrm{H}_{2} \mathrm{~S}$ za utvrđivanje zona zabrane

\begin{tabular}{|c|c|}
\hline \multicolumn{2}{|c|}{ LC for $\mathrm{H}_{2} \mathbf{S}$ Toxic Dispersion } \\
\hline Concentration (ppm) & the exposure time (s) \\
\hline 1000 & 60 \\
\hline 800 & 300 \\
\hline 700 & 600 \\
\hline 50 & 1300 \\
\hline
\end{tabular}

Table 4. Table 4. Toxicity criteria of $\mathrm{H}_{2} \mathrm{~S}$ for determination of the restricted areas

Tablica 4. Kriteriji toksičnosti $\mathrm{H}_{2} \mathrm{~S}$ za utvrđivanje zona zabrane

\begin{tabular}{|c|c||}
\hline \multicolumn{2}{|c||}{ IDLH for $\mathbf{H}_{2} \mathbf{S}$ Toxic Dispersion } \\
\hline Concentration $(\mathbf{p p m})$ & the exposure time (s) \\
\hline 500 & 60 \\
\hline 400 & 300 \\
\hline 360 & 600 \\
\hline 300 & 1800 \\
\hline
\end{tabular}

The findings of this study further indicated the important point that the hazards distance regarding $\mathrm{LC}$ for $\mathrm{H}_{2} \mathrm{~S}$ Toxic Dispersion was $224 \mathrm{~m}$ (Table 5) for the restricted area and it was $386 \mathrm{~m}$ (Table 6) regarding IDLH for $\mathrm{H}_{2} \mathrm{~S}$ Toxic Dispersion for the impacted area.

Now, considering the 200 meters distance of the ENI camp from danger area in which 600 people including the NIOPDC personnel reside, it is rendered as mandatory to evacuate this camp due to its proximity with (adjacency to) refinery pollutants.

\section{DISCUSSION}

Much research has been done and many measures have been taken over the last decades to prevent the incidence of potential disastrous accidents and promote the safety level in chemical processes. The result has been systematic management of safety in these processes. One of

Table 5. Table 5. Hazard radius relating to the restricted area

Tablica 5. Radijus opasnosti za zonu zabrane

\begin{tabular}{|c|c|c|c|c|c|c|c|c|c|}
\hline \multicolumn{10}{|c|}{ LC for $\mathrm{H}_{2} \mathrm{~S}$ Toxic Dispersion } \\
\hline \multirow{3}{*}{$\begin{array}{c}\text { Concen- } \\
\text { tration } \\
(p p m)\end{array}$} & \multirow{3}{*}{$\begin{array}{l}\text { The Exposure } \\
\text { Time (s) }\end{array}$} & \multicolumn{3}{|c|}{ The modeled hazard Distance (m) } & \multicolumn{3}{|c|}{$\begin{array}{l}\mathrm{H}_{2} \mathrm{~S} \text { Concentration in the fence } \\
\text { location }(340 \mathrm{~m})\end{array}$} & \multicolumn{2}{|c|}{$\begin{array}{l}\text { The width of vapor } \\
\text { Cloud }\end{array}$} \\
\hline & & \multicolumn{3}{|c|}{ Velocity of Wind $(\mathrm{m} / \mathrm{s})$} & \multicolumn{3}{|c|}{ Velocity of wind (m/s) } & \multicolumn{2}{|c|}{ Velocity of wind $(\mathrm{m} / \mathrm{s})$} \\
\hline & & 2 & 5 & 16 & 2 & 5 & 16 & 2 & 5 \\
\hline 1000 & 60 & 72 & 74 & 81 & 330 & 330 & 270 & - & - \\
\hline 800 & 300 & 102 & 107 & 122 & 300 & 330 & 240 & - & - \\
\hline 700 & 600 & 122 & 133 & 150 & 340 & 360 & 240 & - & - \\
\hline 500 & 1800 & 191 & 224 & 214 & 330 & 360 & 240 & - & - \\
\hline \multicolumn{2}{|c|}{ Dispersion Rate (kg/s) } & \multicolumn{8}{|c|}{283.31} \\
\hline
\end{tabular}

Table 6. Hazard radius relating to the impacted area

Tablica 6. Radijus opasnosti za zahvaćenu zonu

\begin{tabular}{|c|c|c|c|c|c|c|c|c|c|}
\hline \multicolumn{10}{|c|}{ IDLH for $\mathrm{H}_{2} \mathrm{~S}$ Toxic Dispersion } \\
\hline \multirow{3}{*}{$\begin{array}{l}\text { Concen- } \\
\text { tration } \\
(p p m)\end{array}$} & \multirow{3}{*}{$\begin{array}{l}\text { The Expo- } \\
\text { sure Time } \\
\text { (s) }\end{array}$} & \multirow{2}{*}{\multicolumn{3}{|c|}{$\begin{array}{c}\text { The modeled hazard Distance }(\mathrm{m}) \\
\text { Velocity of Wind }(\mathrm{m} / \mathrm{s})\end{array}$}} & \multirow{2}{*}{\multicolumn{3}{|c|}{$\begin{array}{c}\mathrm{H}_{2} \mathrm{~S} \text { Concentration in the fence } \\
\text { location }(340 \mathrm{~m})\end{array}$}} & \multirow{2}{*}{\multicolumn{2}{|c|}{$\begin{array}{c}\begin{array}{l}\text { The width of vapor } \\
\text { Cloud }\end{array} \\
\text { Velocity of wind }(\mathrm{m} / \mathrm{s})\end{array}$}} \\
\hline & & & & & & & & & \\
\hline & & 2 & 5 & 16 & 2 & 5 & 16 & 2 & 5 \\
\hline 500 & 60 & 191 & 221 & 214 & 302 & 360 & 240 & - & - \\
\hline 400 & 300 & 255 & 297 & 259 & 302 & 360 & 240 & - & - \\
\hline 360 & 600 & 290 & 329 & 280 & 340 & 332 & 240 & 30 & 28 \\
\hline 300 & 1800 & 355 & 386 & 308 & 340 & 362 & 240 & 38 & 40 \\
\hline \multicolumn{2}{|c|}{ Dispersion Rate (kg/s) } & \multicolumn{8}{|c|}{283.31} \\
\hline
\end{tabular}


the basic elements of safety management systems is the identification of dangers, risk assessment, and the scenarios of probable accidents and their consequences. This would aid the safety experts to perform the required investigations and use them in logical decision making to reduce the likelihood of the occurrence of accidents and their consequences (Rusin \& Stolecka, 2015). The exact speculation and determination of accidents and the consequences of activities of chemical industries is the crux of a stubborn problem and the direct and indirect erroneous costs of these industries is extremely vast. Thus, regarding these issues, the efforts of the chemical industries to prevent damage and loss seems to be natural. Paying attention to the safety of installations and constructions and the related hazards and their effects on humanity and daily routine lives of the societies affected by them should be highlighted. In the past, it was solely after the incidence of accidents that their causes were investigated and the damages and great losses were calculated. On the contrary, to day, the problematic points and critical areas could be determined beforehand due to the availability of various risk assessment methods and analysis of consequences of scenarios of accidents. Measures can be taken to identify the type of accidents and control them (Rusin \& Stolecka, 2015). Proliferative research has been conducted so far on consequence modeling and analysis of consequences of leakage, fire, explosion, and the effect (impact) boundary around the danger source. The study by Spyros Sklavounos (2003) entitled: "Determination of Safe Distance in Proximity of Gas Fuel Pipelines" demonstrated that regarding the environmental and structural conditions, the safety ray was 850 meters (Sklavounos \& Rigas, 2006). Also, in the study by Matthijsen entitled: "The Safe Distance of Hydrogen Charging Stations" the safe process distance was estimated to be 410 meters (Matthijsen \& Kooi, 2006). The study by Rigas et al. entitled: "Determination of Safe Distance for Accessing Explosive Materials Pipelines" revealed that a distance of at least 1240 meters should be considered for any type of building operations (Rigas \& Sebos, 1998). Moreover, the study by Moonis (2010) conducted on assessing the risk of Hydrogen gas production chain showed that the sudden fire ray due to leakage from hydrogen tanker was 400 meters (Moonis et al., 2010). Further- more, another research carried out by Gorboni and Salvador (2009) demonstrated that the sudden fire ray and eruptive fire due to leakage from Hydrogen gas transmission pipeline were 13 and 30 meters, respectively. In this study, the secure privacy of Hydrogen production process was determined on the basis of risk estimation indicating that the safe distance of Hydrogen production unit is $165 \mathrm{~m}$ (Gerboni \& Salvador, 2011). The present study used PHAST software to model the poisons release model and formation of vapor cloud due to leakage, and the hazard distance form the clot stuck unit and slug-catcher was considered. Also, the findings of this study indicated that the hazard distance was $224 \mathrm{~m}$ and $386 \mathrm{~m}$ for the restricted and impacted areas, respectively. It should be noted that the official-residential camp of ENI with its 600 residents of NIOPDC personnel is 200 meters distant from the danger area. This camp was established in 2001 to be used as the residential place of personnel of the Italian ENI Company. It should be emphasized that after inauguration of phases $2 \& 3$, this camp was submitted to the Iranian side and it had to be evacuated due to its close proximity to the refinery and its pollutants, yet, due to some financial problems this was not done and it is still being used for the residence of the personnel. Consequently, it is notable that this camp is located in the risk zone. Hence, it should be immediately transferred to a new site to reduce the potential human casualties in the case of the incidence of any leakage from the discharge unit.

\section{CONCLUSION}

A quick glance at the role of consequence evaluation clearly betrays how far the nature of consequence assessment can cover the deficiencies of traditional methods which are mostly based on previous experiences and engineering judgments. The study of consequence assessment can be a useful innovation for determining their newer applications.

\section{REFERENCE}

Advisory Committee on Major Hazards. The control of major hazards. Third report. Her Majesty's Stationery Office. London, 1984. 
Centre for Chemical Process Safety (CCPS), Guidelines for chemical process quantitative risk analysis. American Institute of Chemical Engineers; York: American Institute of Chemical Engineers, 2000.

Centre for Chemical Process Safety (CCPS), Guidelines for Evaluating the Characteristics of Vapour Cloud Explosions, Flash fires, and BLEVEs. New York: American Institute of Chemical Engineers, 1994.

Das, B., Weinberg, M.: Improving flammable mass estimation for vapour cloud explosion modelling in an offshore QRA. Safety science, 50, 2012., 5, 1218-1227.

Dziubiński, M., Frątczak, M., Markowski, A. S.: Aspects of risk analysis associated with major failures of fuel pipelines. Journal of Loss Prevention in the Process Industries, 19, $2006 .$, 5, 399-408.

Gerboni, R., Salvador, E.: Hydrogen transportation systems: Elements of risk analysis. Energy, 34, 2009., 12, 2223-2229.

Jafari, M. J., Zarei, E., Badri, N.: The quantitative risk assessment of a hydrogen generation unit. International Journal of Hydrogen Energy, 37, 2012., 24, 19241-19249.

Jianwen, Z., Da, L., Wenxing, F.: An approach for estimating toxic releases of $\mathrm{H} 2 \mathrm{~S}$ - containing natural gas. Journal of hazardous materials, 264, 2014., 3, 350-362.

Lu, L., Liang, W., Zhang, L., Zhang, H., Lu, Z., Shan, J. A.: comprehensive risk evaluation method for natural gas pipelines by combining a risk matrix with a bow-tie model. Journal of Natural Gas Science and Engineering, 25, 2015., 3, 124-133.

Matthijsen, A., Kooi, E.: Safety distances for hydrogen filling stations. Journal of Loss Prevention in the Process Industries, 6, 2006., 19, 719-723.

McCrea-Strub, A., Kleisner, K., Sumaila, U. R., Swartz, W., Watson, R., Zeller, D., Pauly,
D.: Potential impact of the Deepwater Horizon oil spill on commercial fisheries in the Gulf of Mexico. Fisheries, 36, 2011., 7, 332-336.

Moonis, M., Wilday, A. J., Wardman, M. J.: Semi-quantitative risk assessment of commercial scale supply chain of hydrogen fuel and implications for industry and society. Process Safety and Environmental Protection, 88, 2010., 2, 97-108.

Nadimi, B. S., Arjmand, M., Rashtchean, D., Alinejadshahabi, R.: Dispersion Modelling of Carbon Monoxide (CO) Effluent From Steel Mill Company Stacks. Journal of applied chemistry in environment, 10, 2012., 3, 39-46.

Revie, R.W.: Oil and Gas Pipelines: Integrity and Safety Handbook. John Wiley \& Sons, New York,2015.

Rigas, F., Sebos, I.: Shortcut estimation of safety distances of pipelines from explosives. Journal of transportation engineering, 124, 1998., 2, 200-204.

Rusin, A., Stolecka, K. Reducing the risk level for pipelines transporting carbon dioxide and hydrogen by means of optimal safety valves spacing. Journal of Loss Prevention in the Process Industries, 33, 2015., 6, 77-87.

Rusin, A., Stolecka, K.: Modelling the effects of failure of pipelines transporting hydrogen. Chemical and Process Engineering, 32, 2011. 2, 117-134.

Schubach, S.: Comparison of probity expressions for the prediction of lethality due to toxic exposure, Quantitative Risk Pty Ltd, Vaucluse N.S.W., Australie, 1995.

Sklavounos, S., Rigas, F.: Estimation of safety distances in the vicinity of fuel gas pipelines. Journal of Loss Prevention in the Process Industries, 19, 2006., 1, 24-31.

USA Department of Defence. Military Standard, Procedure for Performing a Failure Mode, Effects and Critically Analysis, Washington DC, 1980. 
Vianello, C., Macchietto, S., Maschio, G.: Conceptual models for $\mathrm{CO}_{2}$ release and risk assessment: a review. Chemical Engineering, 26, 2012., 1, 573-578.
Witkowski, A., Rusin, A., Majkut, M., Rulik, S., Stolecka, K.: Advances in Carbon Dioxide Compression and Pipeline Transportation Processes. Springer, 2015.

\section{PROCJENA SIGURNIH UDALJENOSTI KOD ISTJECANJA I EMISIJA VODIKOVOG SULFIDA IZ PLINSKIH RAFINERIJA}

SAŽETAK: Rafinerijski procesi moraju biti organizirani i održavani tako da jamče sigurnost radnika, susjeda i okoliša. Rafinerije su izvor mnogih nesreća i incidenata budući da su opasne tvari, proizvodi i proizvodni procesi smješteni vrlo blizu. Cilj studije je proučiti posljedice raznih scenarija istjecanja vodikova sulfida u plinskim rafinerijama i utvrditi granice zone opasnosti i rizike svakog scenarija. Priroda studije bila je opisno-analitična, a istraživanje je provedeno u plinskim rafinerijama. Za utvrđivanje načina širenja plina i utjecaja njegova istjecanja primijenjen je PHAST software. Razrađeno je više scenarija, a također su utvrđivani i utjecaji različitih vremenskih uvjeta na te scenarije $i$ to na dvije razine, $L C$ (lethal concentration = smrtonosna koncentracija) i IDLH (immediately dangerous to life or health = neposredna opasnost za život ili zdravlje). Rezultati ukazuju da je zona smrtne opasnosti LC50 pri širenju vodikova sulfida i zona opasnosti širenja otrova 224 odnosno $386 \mathrm{~m}$. Također je utvrđeno da je ENI-jevo boravište za radnike smješteno u zoni utjecaja dominantne struje i to na udaljenosti od samo $200 \mathrm{mod}$ rafinerije. U slučaju istjecanja mogu se očekivati znatni gubici života i štete za zdravlje. Stoga je nužno preseliti boravište radnika na drugu lokaciju i poduzeti mjere tehničke kontrole.

Ključne riječi: nesreće u proizvodnji, plinske rafinerije, istjecanje vodikova sulfida, zona zabrane, zahvaćena zona 